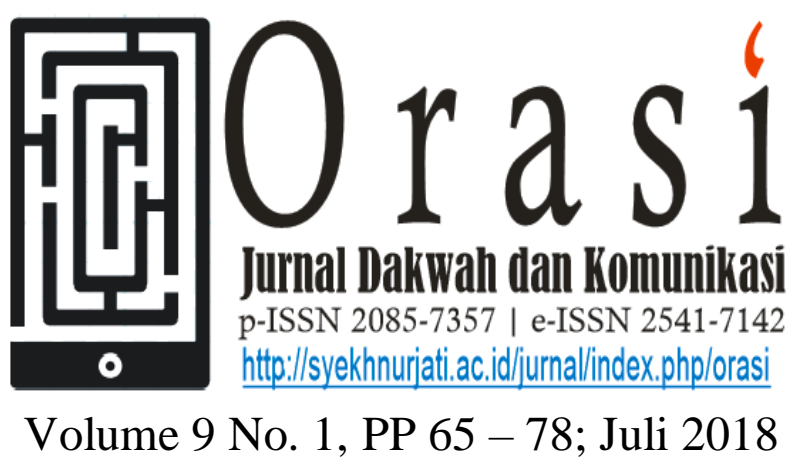

\title{
PENGARUH TAYANGAN ADZAN MAGHRIB TERHADAP KETEPATAN WAKTU SHOLAT TERHADAP IBU-IBU MASYARAKAT DUKUH BOJONG DESA KALIBUNTU KEC LOSARI KAB BREBES
}

\author{
Sri Mega Dimiyati ${ }^{1}$, Abdul Basith2(*) \\ Mahasiswa Jurusan Komunikasi dan Penyiaran Islam ${ }^{1}$ \\ Dosen Fakultas Ushuluddin Adab dan Dakwah ${ }^{2}$ \\ IAIN Syekh Nurjati Cirebon
}

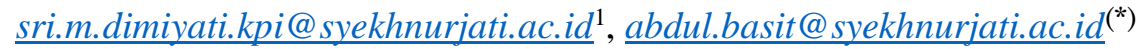

\begin{abstract}
ABSTRAK
Televisi merupakan media massa yang mengalami perkembangan paling fenomenal didunia. Dengan menciptakan suasana tertentu, yaitu menggabungkan antara media dengar dan gambar. Televisi juga bisa dijadikan media dakwah. Adzan adalah panggilan atau seruan untuk segera melaksanakan sholat. Seharusnya ditayangkannya tayangan adzan maghrib ditelevisi membuat orang yang menonton tayangan adzan tersebut segera melaksanakan sholat. Seperti dalam teori hipodermik yang mempunyai asumsi bahwa komponen-komponen komunikasi (komunikator-pesan-media) sangat mempunyai nilai besar dalam mempengaruhi komunikan. Tujuan penelitian ini adalah untuk mengetahui bagaimana tayangan adzan maghrib dalam televisi pada ibu-ibu masyarakat Dukuh Bojong Desa Kalibuntu Kec Losari Kab Brebes. Untuk mengetahui bagaimana ketepatan waktu sholat ibu-ibu masyarakat Dukuh Bojong Desa Kalibuntu Kec Losari Kab Brebes. Dan untuk mengetahui seberapa besar pengaruh tayangan adzan maghrib dalam televisi terhadap ketepatan waktu sholat ibu-ibu masyarakat Dukuh Bojong Desa Kalibuntu Kec Losari Kab Brebes. Penelitian ini menggunakan pendekatan kuantitatif. Data yang digunakan dalam penelitian ini adalah data primer dan sekunder. Dengan jumlah responden $82 i b u-i b u$. Analisis data menggunakan uji validitas, uji reliabilitas, koefesiensi korelasi yang disambung dengan uji determinasi. Semua pengujian tersebut menggunakan alat bantu yaitu program SPSS versi 21.Berdasarkan hasil uji validitas dan reliabilitas setiap item pertanyaan pada variabel $X$ dan variabel $Y$ dinyatakan valid dan reliabel. Serta hasil koefesiensi korelasi yang dilanjut dengan uji determinasi. Tayangan adzan maghrib ditelevisi berpengaruh signifikan terhadap ketepatan waktu sholat ibu-ibu masyarakat Dukuh Bojong Desa Kalibuntu Kec Losari Kab Brebes dengan nilai thitung $(10,465)$ lebih besar dari t tabel (2.10982).
\end{abstract}

Kata Kunci : Tayangan Adzan, Televisi, Ketepatan Waktu Sholat. 


\section{PENDAHULUAN}

Televisi merupakan media massa yang mengalami perkembangan paling fenomenal di dunia. Meski lahir paling belakang dibanding media massa lainnya, seperti media cetak dan radio, namun pada akhirnya media televisilah yang paling banyak diakses oleh masyarakat dimanapun berada di dunia ini. (Badjuri, 2010:11).

Menurut Skornis dalam bukunya "Television and Society. An Incuest and Agenda". (1965), dibandingkan media massa lainnya (radio, surat kabar, majalah, buku, dan sebagainya), televisi mempunyai sifat yang istimewa. Televisi merupakan gabungan dari media dengar dan gambar. Sifat politisnya sangat besar karena bisa menampilkan informasi, hiburan dan pendidikan, atau gabungan dari ketiga unsur tersebut secara kasat mata. (Badjuri, 2010:6).

Televisi menciptakan suasana tertentu, yaitu penonton dapat menikmati acara televisi sambil duduk santai menyaksikan berbagai tayangan ditelevisi atau informasi. Penyampaian isi pesan seolah-olah langsung antara komunikator dan komunikan. Informasi yang disampaikan oleh televisi, dengan mudah dimengerti karena jelas terdengar secara audio dan terlihat secara visual. Pesan-pesan yang disampaikan langsung mempengaruhi otak, emosi, perasaan dan sikap pemirsa atau penonton. Kelebihan televisi ialah dengan adanya satelit komunikasi, cakrawala informasi menjadi semakin luas. Peristiwa disatu tempat dapat dilihat ditempat lain melalui televisi. (Badjuri, 2010:6).

Adzan adalah suatu panggilan untuk sholat. Adzan ini bertujuan untuk masyarakat umum melaksanakan sholat lima waktu dengan tepat waktu. Adzan biasanya terdengar pada mushollah atau masjid yang ada di desa, tetapi dengan perkembangan zaman adzan juga terdapat di dalam tayangan televisi yaitu pada waktu sholat maghrib tiba. Dengan seperti itu peneliti memiliki masalah apakah orang yang melihat tayangan adzan maghrib di televisi itu langsung melaksanakan sholat atau tidak, karena tujuan diadakannya adzan adalah panggilan untuk melaksanakan sholat bukan hanya untuk dilihat dan didengarkan. (Arifinbillah, 1333-121-123)

Faktor-faktor yang televisi menayangkan adzan maghrib dan shubuh yaitu karena waktu sholat yang hanya sebentar. Meminimalisir pemotongan waktu tayang, maka hanya dua adzan sholat saja yang ditayangkan ditelevisi tidak semua adzan sholat lima waktu. Menghargai dan menghormati non muslim walaupun diIndonesia mayoritas muslim, tapi jangan sampai meniadakan non muslim, takutnya 
non muslim merasa terganggu apabila lima waktu sholat adzannya ditayangkan. dan apabila Ramadhan tayangan adzan maghrib juga mengingatkan orang yang berpuasa, untuk berbuka puasa. Serta pada saat adzan shubuh menandakan waktu imsak dating.

Tayangan adzan yang muncul dilayar televisi yaitu bertujuan untuk memberi peringatan kepada orang muslim untuk memenuhi panggilan sholat. Adzan merupakan suatu tanda dimulainya sholat wajib tersebut. Disamping itu masih banyak lagi fungsi lain dari adzan, selain dimasjid atau mushollah, adzan bisa dijumpai di media massa salah satunya adalah di televisi.

Kemasan adzan yang menarik yang ditayangkan ditelevisi sangat menganjurkan orang muslim yang menontonnya untuk beranjak melakukan sholat. Sebagai orang muslim mengikuti ajaran agama sangatlah penting, yaitu salah satunya adalah melaksanakan sholat, apalagi yang diketahui bahwa sholat itu adalah tiang agama. Namun sebagian masyarakat hanya bersantai ketika menjelang sholat atau juga masih asyik untuk menonton televisi, bahkan sampai mengganti channel dan mengesampingkan sholat. Semestinya dengan menayangkan tayangan adzan di televisi apalagi dengan penyajian yang menarik dan sangat bagus, tayangan adzan bisa memberikan kesadaran bahwa saat itu adalah waktunya sholat dan segera mungkin untuk melaksanakan sholat, dengan tidak melanjutkan menonton televisi.

Tayangan adzan maghrib di televisi yang ditonton oleh masyarakat Dukuh Bojong Desa Kalibuntu Kec Losari Kab Brebes mengingatkan peneliti pada teori hipodermik. Model penelitian komunikasi dengan menggunakan teori hipodermik boleh dikatakan model yang paling tua. Model ini mempunyai asumsi bahwa komponen-komponen komunikasi (komunikator-pesan-media) sangat mempunyai nilai besar dalam mempengaruhi komunikan. Disebut teori jarum suntik karena dalam teori ini dikesankan seakan-akan pesan langsung disuntikkan langsung kepada komunikan. Teori ini juga sering disebut dengan "bullet theory" (teori peluru). (Rakhmat, 2012:62). Komunikasi massa (mass communication) ialah komunikasi melalui media massa modern yang meliputi suratkabar yang mempunyai Sirkulasi yang luas Siaran radio dan televisi yang ditujukan kepada umum dan film yang dipertunjukkan di gedung-gedung bioskop. (Effendy, 2003:79). Komunikasi massa adalah proses komunikasi yang dilakukan melalui media massa dengan berbagai tujuan komunikasi dan untuk menyampaikan informasi kepada khalayak luas. (Bungin, 2013:71). Rakhmat merangkum definisi-definisi komunikasi massa tersebut menjadi: "komunikasi massa diartikan sebagai jenis komunikasi yang 
ditujukan kepada sejumlah khalayak yang tersebar, heterogen, dan anonim melalui media cetak atau elektronik sehingga pesan yang sama dapat diterima secara serentak dan sesaat (Rakhmat, 2003: 189).

Televisi secara etimologis berasal dari kata "tele" yang artinya jauh, dan "vision" yang berarti penglihatan, segi jauhnya disamakan dengan prinsip radio yaitu bisa didengar dan penglihatannya adalah gambar. Dengan demikian televisi yang bahasa inggrisnya television diartikan dengan melihat jauh. Melihat jauh disini adalah dengan gambar dan suara yang diproduksi dari suatu tempat dan dapat dilihat dengan menggunakan media televisi. (Effendy, 2003: 174-175).

Stasiun televisi telah menjangkau lapisan masyarakat yang sangat luas. Perkembangannyapun ada, dulu masyarakat dikontrol untuk memperoleh informasi. Namun, masyarakat kini dapat dengan leluasa memilih informasi dan tayangan televisi sesuai dengan selera penonton tersebut. (Ma'arif, 2010:163).

Pengaruh televisi dalam sistem komunikasi tidak akan bisa lepas dari pengaruh terhadap aspek-aspek kehidupan pada umumnya. Bahwa televisi berpengaruh terhadap kehidupan masyarakat Indonesia itu sudah banyak yang mengetahui bahkan merasakannya. Menurut Prof. Dr. R. Mar'at dari UNPAD, acara televisi pada umumnya mempengaruhi sikap, pandangan, persepsi, dan perasaan para penonton, itu semua adalah hal yang wajar terjadi. Karena salah satu pengaruh psikologis dari televisi seakan-akan menghipnotis penonton. (Effendy, 2008:122).

Adzan mulai disyari'atkan pada tahun kedua hijriyah. Pada suatu hari nabi Muhammad SAW membentuk suatu musyawarah dengan para sahabat untuk menentukan bagaimana cara untuk mengumpulkan orang-orang agar segera berkumpul ke masjid ketika telah memasuki waktu sholat. Dan hasil dari musyawarah itu adalah dengan mimpi salah satu sahabat nabi Muhammad kedatangan seseorang yang memberitahu bagaimana cara mengumpulkan orang mukmin untuk segera malaksanakan sholat yaitu dengan adzan. (Arifinbillah, 1333:121-123).

Hanafiyah, Syafi'iyah dan sebagian Malikiyah berpendapat bahwa adzan dan iqomah itu Sunnah muakkadah bagi lakilaki disetiap masjid, baik untuk sholat fardhu maupun untuk sholat jum'at. Namun tidak disunnahkan untuk shalat yang lain, seperti shalat id, shalat gerhana dan shalat Sunnah lainnya. Imam malik berpendapat wajib adzan dan iqamah untuk shalat berjamaah dosetiap masjid. Adapun kebanyakan hanabilah berpendapat fardhu kifayah untuk sholat fardhu yang dilakukan 
secara ada' (shalat yang dilakukan pada waktunya) dan sholat jum'at. Zhahiriyah berpendapat bahwa adzan untuk sholat berjamaah itu wajib dan shalat jamaah tidak sah tanpa adzan dan iqamah. Bagi orang yang sholatnya munfarid wajib iqamah dan tidak wajib adzan. Demikian juga bagi jamaah kaum wanita. (Nurkholis, 1995 : 167).

Berikut ini adalah faktor-faktor kenapa cuma adzan maghrib dan shubuh saja yang ditayangkan ditelevisi (versi The Unique History) yaitu :

1. Waktu Yang Hanya Sebentar

Alasan pertama adalah waktu sholat subuh dan maghrib yang hanya sebentar, seperti yang di ketahui waktu sholat shubuh akan habis jika matahari terbit, begitu juga pada sholat maghrib yang akan berakhir pada isya' berkumandang.

Dalam hal ini pihak televisi menayangkan adzan shubuh dan maghrib dengan tujuan mengingatkan kepada semua muslim yang ada di Indonesia, karena mengingat bahwa mayoritas orang-orang indonesia adalah beragama islam, dan juga mengingat waktu sholat shubuh dan maghrib yang relatif singkat.

2. Pemotongan Waktu Tayang

Apabila semua waktu adzan harus dikumandangkan ditelevisi maka hal ini akan membuat pihak televisi memotong waktu tayang sebuah film dengan beberapa kali pemotongan, karena bagaimanapun jika banyak yang harus di potong waktu tayang akan membuat film-film yang tayang pada televisi akan menjadi membingungkan. Maka dari itu televisi hanya menampilkan adzan shubuh dan maghrib saja. Sehingga pihak stasiun televisi sedikit memotong waktu tayang film-film tersebut.

3. Menghargai dan Menghormati Non Muslim

Indonesia adalah negara yang beragam, baik itu dari budaya, warna kulit, adat istiadat sampai ke agama. di indonesia sendiri terdapat 6 agama yang telah diakui, yakni seperti agama Islam, Kristen Protestan, Kristen Katholik, Buddha, Hindu dan Kong $\mathrm{Hu}$ $\mathrm{Cu}$. Mengingat Indonesia terdiri dari berbagai agama, apabila setiap waktu adzan harus dikumandangkan ditelevisi maka hal ini bisa membuat non muslim terganggu.

\section{Sebagai Pengingat Waktu Imsak}

Dan Buka Puasa

Dalam kaitannya dengan bulan ramadhan, inilah alasan yang memungkinkan kenapa hanya adzan shubuh dan maghrib saja yang berkumandang di televisi. yakni shubuh sebagai tanda waktu imsak telah tiba. Serta adzan maghrib untuk 
mengingatkan tanda waktu berbuka puasa bagi umat islam yang sedang berpuasa.

\section{METODOLOGI PENELITIAN}

Penelitian kuantitatif adalah suatu proses untuk menemukan pengetahuan dengan menggunakan data berupa angka sebagai alat menemukan keterangan mengenai apa yang ingin kita ketahui (Darmawan, 2013: 37). Pengertian lain menyebutkan, penelitian kuantitatif merupakan kajian yang menggunakan analisis statistik untuk mendapatkan temuannya. Ciri utamanya mencakup pengukuran formal dan sistematis dan penggunaan statistik (Suharsaputra, 2012: 49).

Penelitian ini menggunakan pendekatan penelitian kausal-comparatif (causal comparative research) yaitu bertujuan untuk menyelidiki kemungkinan hubungan sebab-akibat dengan cara: berdasarkan dengan pengamatan terhadap akibat yang ada mencari kembali faktor yang mungkin menjadi penyebab melalui data tertentu. (Suryabrata, 1997:26).

Sumber data dalam penelitian ini menggunakan data sekunder dan data primer. Data sekunder adalah data yang sudah tersedia, sehingga peneliti tinggal mencari dan mengumpulkannya. Data ini bisa diperoleh di perpustakaan, kantor pemerintah, biro statistic dan lain-lain. Meskipun data sekunder secara fisik telah tersedia, peneliti tidak boleh gegabah untuk menggunakannya. Untuk mendapatkan data yang tepat dan sesuai dengan tujuan penelitian (Sarwono, 2006:11-12). Data primer adalah data yang berasal dari sumber asli atau pertama. Data ini tidak tersedia dalam bentuk terkompilasi ataupun dalam bentuk file-file. Data ini harus dicari melalui narasumber atau dalam istilah teknisnya responden, yaitu orang yang dijadikan obyek penelitian atau orang yang dijadikan sebagai sarana mendapatkan informasi ataupun data. (Sarwono, 2006:8).

Populasi adalah sumber data penelitian tertentu yang memiliki jumlah banyak dan luas (Darmawan, 2013: 137). Populasi dalam penelitian ini adalah seluruh ibu-ibu masyarakat Dukuh Bojong Desa Kalibuntu Kec Losari Kab Brebes, menurut keterangan dari aparat desa yaitu berjumlah 450 .

Teknik penarikan sampel bisa juga menggunakan metode ini adalah populasi dibagi dulu atas kelompok berdasarkan area atau cluster, lalu kemudian dari beberapa cluster dipilih sebagai sampel, dari cluster tersebut bisa diambil keseluruhannya atau sebagian saja untuk dijadikan sampel. Anggota populasi disetiap cluster tidak perlu homogen. Sampel ditarik dengan teknik kombinasi antara stratified sampling 
dan cluster sampling. (Siregar, 2010:147).

Teknik pengumpulan data yang digunakan dalam penelitian ini berupa angket, observasi dan dokumentasi. Adapun

\section{Hasil dan Pembahasan}

Penyebaran angket dari data tentang pengaruh tayangan adzan maghrib di televisi terhadap ketepatan waktu sholat (studi masyarakat Dukuh Bojong Desa Kalibuntu Kec Losari Kab Brebes) kepada 82 masyarakat ibu-ibu yang dijadikan sampel dalam penelitian ini. Angket tentang tayangan adzan maghrib ditelevisi berjumlah 24 butir pertanyaan dan angket tentang ketepatan waktu sholat ibu-ibu teknik analisis data yang digunakan yaitu korelasi product momen dan pengujian hipotesis menggunakan rumus uji t.

masyarakat Dukuh Bojong Desa Kalibuntu Kec Losari Kab Brebes berjumlah 15 butir pertanyaan. Angket ini menggunakan skala rikert, dengan alternatif jawaban yang terdiri dari sangat setuju (SS), setuju (S), ragu-ragu (RR), tidak setuju (TS), dan sangat tidak setuju (STS).

Pada Table 1 item nomor 1 tentang media yang dimiliki responden, responden merespon seperti berikut :

Tabel 1 Media Elektronik yang dimiliki responden

\begin{tabular}{|c|c|c|c|}
\hline & Pernyataan & $\mathrm{F}$ & $\%$ \\
\hline 1.00 & Televisi & 13 & 15.9 \\
\hline 2.00 & Televisi \& Radio & 3 & 3.7 \\
\hline 3.00 & Televisi \& Surat Kabar & 3 & 3.7 \\
\hline 4.00 & Televisi \& Majalah & 1 & 1.2 \\
\hline 5.00 & Televisi \& Smart Phone & 57 & 69.5 \\
\hline 6.00 & Televisi, Radio \& Smart Phone & 2 & 2.4 \\
\hline 7.00 & Televisi, Surat Kabar \& Smart Phone & 2 & 2.4 \\
\hline \multirow[t]{2}{*}{8.00} & Televisi, Majalah \& Smart Phone & 1 & 1.2 \\
\hline & Total & 82 & 100 \\
\hline
\end{tabular}

Dengan demikian sebagian besar responden memiliki media yaitu televisi dan smart phone, yang memiliki tingkat pemilih sebanyak 57 responden atau $69.5 \%$.

Televisi merupakan media terpopuler di Indonesia, karena televisi memiliki keunggulan yaitu gambar dan suara. Sehingga responden lebih tertarik untuk memiliki media televisi. Sedangkan smart phone adalah salah satu alat untuk memudahkan komunikasi.

Pada item nomor 2 tentang media yang sering digunakan responden, responden merespon seperti pada tabel dihalaman berikut : 
Tabel 2 Media yang sering digunakan responden

\begin{tabular}{|c|c|c|c|}
\hline & Pernyataan & Frequency & Percent \\
\hline 1.00 & Televisi & 29 & 35.7 \\
\hline 2.00 & Televisi \& Surat Kabar & 1 & 1.2 \\
\hline 3.00 & Televisi \& Majalah & 1 & 1.2 \\
\hline 4.00 & Televisi \& Smart Phone & 50 & 61 \\
\hline 5.00 & $\begin{array}{c}\text { Televisi, Surat Kabar \& Smart } \\
\text { Phone }\end{array}$ & 1 & 1.2 \\
\hline & Total & 82 & 100 \\
\hline
\end{tabular}

Dengan demikian sebagian besar responden sering menggunakan media yaitu televisi dan smart phone, yang memiliki tingkat pemilih sebanyak 50 responden atau $61 \%$.

Pada tabel item nomor 3 tentang stasiun televisi yang ada pada televisi responden, hasil pengamatan seperti tabel berikut ini.

Tabel 3 Stasiun Televisi yang ada pada Televisi responden

\begin{tabular}{|c|c|c|c|}
\hline & Pernyataan & $\mathrm{f}$ & $\%$ \\
\hline \multirow[b]{2}{*}{1.00} & TVRI RCTI, SCTV, MNCTV, ANTV, INDOSIAR, METRO TV & 2 & 2.4 \\
\hline & TRANS TV, TRANS7, TVONE, GTV, KOMPAS TV \& NET & & \\
\hline \multirow[t]{2}{*}{2.00} & TVRI, RCTI, SCTV, MNCTV, ANTV, INDOSIAR, METRO TV & 2 & 2.4 \\
\hline & $\begin{array}{c}\text { TRANS TV, TRANS7, TVONE, GTV, KOMPAS TV, NET \& } \\
\text { RTV }\end{array}$ & & \\
\hline \multirow[t]{2}{*}{3.00} & TVRI, RCTI, SCTV, MNCTV, ANTV, INDOSIAR & 28 & 34.1 \\
\hline & METRO TV, TRANS TV, TRANS7, TVONE, GTV \& NET & & \\
\hline \multirow[t]{2}{*}{4.00} & RCTI, SCTV, MNCTV, ANTV, INDOSIAR, METRO TV & 22 & 26.8 \\
\hline & TRANS TV, TRANS7, TVONE, GTV \& NET & & \\
\hline \multirow[t]{2}{*}{5.00} & TVRI, RCTI, SCTV, MNCTV, ANTV, INDOSIAR & 2 & 2.4 \\
\hline & METRO TV, TRANS TV, TRANS7, TVONE, RTV \& iNEWS & & \\
\hline \multirow[t]{2}{*}{6.00} & TVRI, RCTI, SCTV, MNCTV, ANTV, INDOSIAR, METRO TV & 4 & 4.9 \\
\hline & TRANS TV TRANS7, TVONE, GTV, NET \& RTV & & \\
\hline 7.00 & $\begin{array}{c}\text { RCTI, SCTV, MNCTV, ANTV, INDOSIAR, METRO TV, } \\
\text { TRANS TV } \\
\text { TRANS7, TVONE, GTV, NET, RTV \& iNEWS }\end{array}$ & 6 & 7.3 \\
\hline \multirow[t]{2}{*}{8.00} & $\begin{array}{r}\text { TVRI, RCTI, SCTV, MNCTV, ANTV, INDOSIAR, METRO } \\
\text { TV, TRANS TV } \\
\text { TRANS7, TVONE, GTV, KOMPAS TV, NET, RTV, iNEWS \& RCTV } \\
\text { (Radar Cirebon TV) }\end{array}$ & 16 & 19.5 \\
\hline & Total & 82 & 100 \\
\hline
\end{tabular}


Dengan demikian sebagian kecil responden memiliki stasiun televisi sebagai berikut : TVRI, RCTI, SCTV, MNCTV, ANTV, INDOSIAR, METRO TV, TRANS

Pada item nomer 4 yang berisi tentang jumlah responden yang menonton acara yang ditayangkan oleh stasiun televisi pada jam 17.00-18.10 WIB. Responden merespon sangat setuju sebanyak 55 responden atau $67,1 \%, 24$ responden menyatakan setuju atau $29,3 \%$ dan 3 responden menyatakan ragu-ragu atau $3,7 \%$. Dengan demikian sebagian besar responden menonton acara yang ditayangkan oleh stasiun televisi pada jam 17.00-18.10 WIB, yang hasilnya 55 responden atau $67.1 \%$.

Pada item nomer 5 yang berisi tentang cara responden menonton acara yang ditayangkan oleh stasiun televisi pada jam 17.00-18.10. responden merespon seperti berikut:

\section{Tabel 6}

Frekuensi Cara Responden yang menonton acara yang ditayangkan oleh stasiun televisi pada jam 17.00-18.10 WIB

\begin{tabular}{|l|c|c|c|}
\hline & Pernyataan & $f$ & $\%$ \\
\hline 2.00 & Anak-anak & 27 & 32.9 \\
\hline 3.00 & Suami & 1 & 1.2 \\
\hline 4.00 & Orang tua & 1 & 1.2 \\
\hline 5.00 & Sekeluarga & 53 & 64.6 \\
\hline & Total & 82 & 100 \\
\hline
\end{tabular}

Dengan demikian sebagian besar
TV, TRANS7, TVONE, GTV \& NET yang memiliki tingkat pemilih sebanyak 28 responden atau $34.1 \%$.

responden selalu menonton acara yang ditayangkan oleh stasiun televisi pada jam 17.00-18.10 dengan keluarga. Yang memiliki tingkat pemilih 53 responden atau $64,6 \%$.

Untuk mengetahui tentang stasiun televisi yang dipilih responden untuk menonton tayangan adzan maghrib dapat dilihat pada tabel dibawah ini:

Pada item nomer 6 yang berisi tentang stasiun televisi yang dipilih responden untuk menonton tayangan adzan maghrib. Responden merespon seperti yang terdapat pada tabel dibawah ini:

Tabel 8

Frekuensi Stasiun televisi yang dipilih responden untuk menonton tayangan adzan maghrib

\begin{tabular}{|c|c|c|c|}
\hline No & Pernyataan & $f$ & $\%$ \\
\hline 1.00 & TVRI & 3 & 3.7 \\
\hline 2.00 & RCTV & 7 & 8.5 \\
\hline 3.00 & SCTV & 5 & 6.1 \\
\hline 4.00 & MNCTV & 11 & 13.4 \\
\hline 5.00 & ANTV & 10 & 12.2 \\
\hline 6.00 & INDOSIAR & 7 & 8.5 \\
\hline 8.00 & TRANS TV & 3 & 3.7 \\
\hline 9.00 & TRANS7 & 10 & 12.2 \\
\hline 11.00 & GTV & 24 & 29.3 \\
\hline \multirow[t]{2}{*}{13.00} & NET & 2 & 2.4 \\
\hline & Total & 82 & 100 \\
\hline
\end{tabular}

responden menonton tayangan adzan 
maghrib di stasiun televisi GTV yang memiliki tingkat pemilih sebanyak 24 responden atau $29,3 \%$.

Pada item nomer 7 yang berisi tentang tujuan responden menonton acara di televisi pada jam 17.00-18.10. Responden merespon seperti yang terdapat pada tabel dibawah ini:

Tabel 10

Frekuensi Tujuan responden menonton acara di televisi pada jam 17.00-18.10

\begin{tabular}{|c|c|c|c|}
\hline No & Pernyataan & $\mathrm{F}$ & $\%$ \\
\hline 1.00 & Hiburan & 26 & 31.7 \\
\hline 2.00 & Mencari informasi & 4 & 4.9 \\
\hline 3.00 & Bersantai & 36 & 43.9 \\
\hline 4.00 & $\begin{array}{c}\text { Menunggu adzan } \\
\text { maghrib }\end{array}$ & 14 & 17.1 \\
\hline 5.00 & Menghabiskan waktu & 2 & 2.4 \\
\hline & Total & 82 & 100 \\
\hline
\end{tabular}

Pada item nomer 9 yang berisi tentang responden yang menonton tayangan adzan maghrib ditelevisi dari awal sampai selesai. Responden merespon sangat setuju sebanyak 54 responden atau 65,9\%, 23 responden menyatakan setuju atau 28\%, 4 responden menyatakan ragu-ragu atau 4,9\% dan 1 responden menyatakan tidak setuju atau $1,2 \%$. Dengan demikian sebagian besar responden menonton tayangan adzan maghrib ditelevisi dari awal sampai selesai, yang hasilnya adalah 54 responden atau $65.9 \%$.

Untuk mengetahui tentang jumlah responden yang tertarik dengan tayangan adzan maghrib ditelevisi yang ditontonnya,
Dengan demikian hampir setengahnya responden menonton acara di televisi pada jam 17.00-18.10 adalah untuk bersantai dengan tingkat pemilih sebanyak 36 responden atau $43,9 \%$.

Pada item nomer 8 yang berisi tentang jumlah responden yang menonton tayangan adzan maghrib di stasiun televisi setiap hari. Responden merespon sangat setuju sebanyak 51 responden atau $62.2 \%, 28$ responden menyatakan setuju atau $34.1 \%$ dan 3 responden menyatakan ragu-ragu atau 3.7\%. Dengan demikian sebagian besar responden menonton tayangan adzan maghrib di stasiun televisi setiap hari, yang hasilnya adalah 51 responden atau $62.2 \%$. dapat dilihat pada tabel dibawah ini:

Pada item nomer 10 yang berisi tentang jumlah ketertarikan responden dengan suara muadzin yang ditayangkan di stasiun televisi yang ditonton. Responden merespon sangat setuju sebanyak 57 responden atau 69,5\%, 19 responden menyatakan setuju atau $23,2 \%, 5$ responden menyatakan ragu-ragu atau $6,1 \%$ dan 1 responden menyatakan tidak setuju atau 1,2\% . Dengan demikian sebagian besar responden tertarik dengan suara muadzin yang ditayangkan di stasiun televisi tersebut, yang hasilnya adalah 57 responden atau $69.5 \%$.

Untuk mengetahui respon masyarakat 
tentang lafadz-lafadz adzan yang terdapat ditayangan adzan maghrib ditelevisi yang sangat jelas, dapat dilihat pada tabel dibawah ini:

Pada item nomer 11 yang berisi mengetahui respon masyarakat tentang lafadz- lafadz adzan yang terdapat pada tayangan adzan maghrib ditelevisi yang sangat jelas. Responden merespon sangat setuju sebanyak 55 responden atau $67,1 \%$, 23 responden menyatakan setuju atau $28 \%$ dan 4 responden menyatakan ragu-ragu atau 4,9\%. Dengan demikian sebagian besar responden menyetujui bahwa lafadz-lafadz adzan yang terdapat ditayangan adzan maghrib ditelevisi sangat jelas, yang hasilnya adalah 55 responden atau $67.1 \%$.

Pada item nomer 12 yang berisi respon masyarakat tentang lafadz-lafadz adzan yang terdapat ditayangan adzan maghrib ditelevisi hurufnya besar-besar. Responden merespon sangat setuju sebanyak 51 responden atau 62,2\%, 25 responden menyatakan setuju atau 30,5\%, 5 responden menyatakan ragu-ragu atau $6,1 \%$ dan 1 responden menyatakan tidak setuju atau $1,2 \%$. Dengan demikian sebagian besar responden menyetujui bahwa lafadz-lafadz adzan yang terdapat ditayangan adzan maghrib ditelevisi hurufnya besar-besar, yang hasilnya adalah 51 responden atau $62.2 \%$.

Pada item nomer 13 yang berisi respon masyarakat tentang lafadz-lafadz adzan yang terdapat ditayangan adzan maghrib ditelevisi mudah dibaca. Responden merespon sangat setuju sebanyak 51 responden atau 62,2\%, 26 responden menyatakan setuju atau 31,7\%, 4 responden menyatakan ragu-ragu atau $4,9 \%$ dan 1 responden menyatakan tidak setuju atau $1,2 \%$. Dengan demikian sebagian besar responden menyetujui bahwa lafadzlafadz adzan yang terdapat ditayangan adzan maghrib ditelevisi mudah dibaca, yang hasilnya adalah 51 responden atau $62.2 \%$.

Selanjutnya uji hipotesis berdasarkan data yang diperoleh dengan berbantuan software SPSS 20. Hasil uji hipotesis sebagai berikut: 
Tabel 4 Hasil Uji Hipotesis

\begin{tabular}{|c|c|c|c|c|c|}
\hline \multirow[t]{2}{*}{ Model } & \multicolumn{2}{|c|}{ Unstandardized Coefficients } & \multirow{2}{*}{$\begin{array}{c}\begin{array}{c}\text { Standardized } \\
\text { Coefficients }\end{array} \\
\text { Beta }\end{array}$} & \multirow[t]{2}{*}{$t$} & \multirow[t]{2}{*}{ Sig. } \\
\hline & $\mathrm{B}$ & Std. Error & & & \\
\hline (Constant) & 10.173 & 5.607 & & 1.814 & .073 \\
\hline tayangan adzan maghrib & .752 & .072 & .760 & 10.465 & .000 \\
\hline
\end{tabular}

Berdasarkan hasil uji di atas nilai signifikan sebesar 0,000. Karena nilai signifikan lebih kecil dari 0,10 dan t hitung $(10,465)$ lebih besar dari t tabel (1.29222) maka Ho ditolak, artinya bahwa ada pengaruh yang signifikan antara tayangan adzan maghrib terhadap ketepatan waktu sholat ibu-ibu masyarakat Dukuh Bojong Desa Kalibuntu Kec Losari Kab Brebes.

Walaupun hasilnya adalah ada pengaruh yang signifikan antara tayangan adzan maghrib terhadap ketepatan waktu sholat ibu-ibu masyarakat Dukuh Bojong Desa Kalibuntu Kec Losari Kab Brebes, dalam hal ini berarti teori jarum suntik ini dibuktikan. Tetapi tidak semua media harus menggunakan teori jarum suntik. Karena ada banyak teori- teori yang bisa digunakan untuk meneliti media selain teor jarum suntik.

Yang disebabkan keberadaan masyarakat yang tidak lagi homogeny dapat mengikis teori jarum suntik ini, karena tingkat pendidikan masyarakat yang semakin meningkat. Meningkatnya jumlah media massa, sehingga masyarakat bisa menentukan sendiri pilihan yang menurutnya menarik. Dan bisa juga dengan adanya peran kelompok yang juga menjadi dasar audience untuk menerima pesan dari media

\section{Simpulan dan Saran}

Berdasarkan hasil penelitian dan hasil uji hipotesis, secara keseluruhan penelitian ini dapat diambil kesimpulan sebagai berikut :

1. Hasil analisis mengenai tayangan adzan maghrib ditelevisi pada ibu-ibu masyarakat Dukuh Bujong Desa Kalibuntu Kec Losari Kab Brebes adalah sebagian besar responden menyatakan bahwa sangat setuju dengan pernyataan-pernyataan tentang tayangan adzan maghrib ditelevisi. Dapat dibuktikan dengan nilai rata-rata sebesar $64.8 \%$. Sehingga dapat disimpulkan bahwa sebagian besar ibu-ibu masyarakat Dukuh Bujong Desa Kalibuntu Kec Losari Kab Brebes mengetahui dan mengerti tentang tayangan adzan 
maghrib ditelevisi.

2. Hasil analisis mengenai ketepatan waktu sholat ibu-ibu masyarakat Dukuh Bujong Desa Kalibuntu Kec Losari Kab Brebes adalah sebagian besar responden menyatakan bahwa sangat setuju dengan pernyataanpernyataan tentang ketepatan waktu sholat. Dapat dibuktikan dengan nilai rata-rata sebesar $66.4 \%$. sehingga dapat disimpulkan bahwa sebagian besar ibu-ibu masyarakat Dukuh Bujong Desa Kalibuntu Kec Losari Kab Brebes melaksanakan sholat tepat waktu.

3. Hasil analisis menunjukkan bahwa terdapat pengaruh yang signifikan antara tayangan adzan maghrib di televisi dengan ketepatan sholat masyarakat Dukuh Bujong Desa Kalibuntu Kec Losari Kab Brebes, yang dibuktikan dengan nilai $\mathrm{t}$ hitung $(10,465)$ lebih besar dari $\mathrm{t}$ tabel (2.10982). dengan demikian hipotesis nol atau $\mathrm{H}_{\mathrm{o}}$ ditolak dan hipotesis alternatif atau $\mathrm{H}_{\mathrm{a}}$ diterima. Penelitian ini menyimpilkan bahwa ibu-ibu masyarakat Dukuh Bujong Desa Kalibuntu Kec Losari Kab Brebes melakukan sholat maghrib secara tepat waktu, dikarenakan adanya tayangan adzan maghrib ditelevisi

\section{Saran}

Saran yang dapat diberikan peneliti setelah melakukan penelitian adalah sebagai berikut :

1. Berdasarkan hasil penelitian yaitu, tayangan adzan maghrib ditelevisi pada ibu-ibu masyarakat Dukuh Bujong, Desa Kalibuntu Kec Losari Kab. Brebes, tentang ketertarikan responden terhadap alur cerita yang ditampilkan pada tayangan adzan maghrib ditelevisi, memiliki tingkat presentase yang paling rendah. Maka dari itu Peneliti menyarankan kepada pihak stasiun televisi untuk membuat alur cerita, pada tayangan adzan maghrib yang lebih menarik. Sehingga masyarakat lebih tertarik untuk menonton tayangan adzan maghrib ditelevisi.

2. Berdasarkan hasil penelitian yaitu, ketepatan waktu sholat ibu-ibu masyarakat Dukuh Bujong, Desa Kalibuntu Kec. Losari Kab. Brebes, tentang pengetahuan responden terhadap adanya alur cerita pada tayangan adzan maghrib ditelevisi, memiliki tingkat presentase yang paling rendah. Maka dari itu Peneliti menyarankan kepada pihak stasiun televisi untuk mengemas alur cerita, pada tayangan adzan maghrib yang lebih mudah dipahami. Sehingga penonton mengetahui tentang alur cerita yang ditayangkan. 


\section{DAFTAR PUSTAKA}

Aziz, Moh ali. (2012). Ilmu Dakwah. Jakarta : Kencana Prenada Media Group

Effendy, onong uchjana. (2003). Ilmu, Teori dan Filsafat Komunikasi. Bandung : PT Citra Aditya Bakti

Bungin, Burhan. 2013. Metodologi Penelitian Kuantitatif: Komunikasi, Ekonomi, dan Kebijakan Publik serta Ilmu-ilmu Sosial Lainnya. Jakarta: Kencana Prenada Media Group

Morisan, dkk. (2013). Teori Komunikasi Massa. Bogor : Ghalia Indonesia

Ma'arif, bambang S. (2010). Komunikasi Dakwah. Bandung : Simbiosa Rekatama Media

Darmawan, deni. (2013). Metode Penelitian Kuantitatif. Bandung : PT Remaja Rodakarya

Suharsaputra, Uhar. 2012. Metode Penelitian: Kuantitatif, Kualitatif, dan Tindakan. Bandung: PT Refika Aditama

Suryabrata, Sumadi. (1997). Metodologi Penelitian. Jakarta: PT Raja Grafindo Persada

Siregar, syofiyan. (2010). Statistika Deskriptif Untuk Penelitian. Jakarta: PT Rajagrafindo Persada 